Савіна Н. Б., А.е.н., проф. (Національний університет водного господарства та природокористування, м. Рівне), Дорощук Н. І., аспірант (Національний університет водного господарства та природокористування, м. Рівне)

\title{
ТЕНДЕНЦІЇ ФІНАНСОВОГО ЗАБЕЗПЕЧЕННЯ ОСВІТНЬОЇ ГАЛУЗІ НАЦІОНАЛЬНОÏ ЕКОНОМІКИ
}

У статті здійснено аналіз динаміки зведеного бюджету освітньої галузі у 2012 - 2017 роках та встановлено, що фактичні видатки на освіту за 2012-2017 роки зросли на 76,2 млн грн. або на 75,0\% в динаміці, з 101,6 млрд грн. у 2012 році до 177,8 млрд грн. у 2017 році. Обгрунтовано зведені витрати на освіту у 2012-2017 роках, доведено, що найбільш суттєвий ріст фактичних видатків на освіту відбувся у 2017 році: +48,3 млрд грн. або 37,3\% до попереднього періоду. Автором проаналізовано витрати на освіту у відсотках до ВВП у 2012-2017 роках та встановлено, що такий показник найвищим був у 2012 р., а найнижчий у 2016 р. За результатами дослідження автором доведено, що найбільша питома вага витрат на освіту припадає на місцеві бюджети, а найменше на державний бюджет. Зокрема у 2012 році місцеві бюджети фінансували $32,2 \%$ витрат на освіту, а в 2017 р. такий показник зменшився до 27,9\%. Для покращення фінансового забезпечення освіти, виходячи із навантаження на місцеві бюджети автором запропоновано оптимізувати систему бюджетування в межах місцевих бюджетів та забезпечити раціональність використання коштів державних бюджетів. Ключові слова: освіта, видатки, зведені видатки, бюджет освітньої галузі, зведені видатки на освіту, фінансування освітньої галузі.

Вступ. Світ переживає революційні зміни в суспільстві, виробництві, в освіті. Реформи в галузі освіти стали центральним елементом розвитку країни. Гонка за першість в сфері освіти вимагає додаткових фінансових ресурсів, а рівень витрат на освіту в значній мірі визначає не тільки економічний потенціал країни, а й формує їі конкурентні переваги на міжнародній арені. Відтак проблема фінансового забезпечення освітньої галузі набуває актуальності та призводить до підвищення зацікавленості освітян, науковців у вирішення даного питання.

Аналіз останніх досліджень і публікацій. Проблеми сучасної 
освітньої галузі досліджені багатьма вітчизняними та зарубіжними ученими, серед яких О.М. Бабіч, О.П. Єфремов, В.А. Жамін, Є.Н. Жильцов, В.М. Зуєв, В.В. Івантер, В.І. Капелюшников, В.Є.Комаров, С.Л. Костанян, Я.І. Кузьмінов, В.І. Марцинкевич, С.Г. Струмилин, В.О. Садовничий, А.І. Субетто, В.М. Филипов, а також Д. Белла, У. Берквіста, М. Баумена, І. Бертрана, Є. Денисона, Дж. М. Кейнс, Е. Тоффлер, Д. Уілер, Т. Шульц та ін. Авторами досліджено внесок освіти в соціально-економічний розвиток країни, обґрунтовано доцільність інвестування освітніх процесів, досліджено ринок освітніх послуг, їх якість та цінність для споживача. Більш детально Вітренко Ю. [1] розкривала сутність освіти як виду економічної діяльності, Головня О.М. [2] в своїх працях розкривала соціальноекономічні джерела розбудови освітнього простору України; Заглинська Л.В., Лукомська О.І. [5] досліджували економічну освіту в контексті інвестиційних процесів у галузі оновлення змісту, форм та методів навчання і виховання в закладах освіти;. Колот А.М. [7] більш детально досліджував сучасний стан, тенденції розвитку вищої освіти як чинника формування людського капіталу; Красовська О.Ю. [8] детально обґрунтовувала сучасні моделі реалізації бізнес-освіти в умовах глобалізації світового освітнього простору.

Попри наявний арсенал наукових розробок в сфері освіти досить мало уваги науковцями приділено вивченню основних тенденції фінансового забезпечення освітньої галузі національної економіки.

Метою даної статті $€$ обґрунтування основних тенденції фінансового забезпечення освітньої галузі національної економіки.

Результати дослідження. Освіта $€$ фундаментом інтелектуального, культурного, духовного, соціального, економічного розвитку суспільства й держави. Її мета - всебічний розвиток людини як особистості та найвищої цінності суспільства, розвиток її талантів, розумових і фізичних здібностей, виховання високих моральних якостей, формування громадян, здатних до свідомого суспільного вибору, збагачення на цій основі інтелектуального, творчого, культурного потенціалу народу, підвищення освітнього рівня народу, забезпечення народного господарства кваліфікованими фахівцями [9]. Стаття 53 Конституції України гарантує забезпечення державою доступності та безоплатності дошкільної, повної загальної середньої, професійнотехнічної, вищої освіти в державних і комунальних навчальних закладах.

Проаналізуємо загальне фінансове забезпечення освітньої галузі за 2012-2017 роки (табл. 1).

Як бачимо з даних табл. 1 фактичні видатки на освіту за 20122017 роки зросли на 76,2 млн грн. або на 75,0\% в динаміці, 3 
101,6 млрд грн. у 2012 році до 177,8 млрд грн. у 2017 році. За досліджуваний період зросли зведені видатки на освіту, проте в перерахунку на дол. США вони зменшилися, що пов'язано зі зростанням курсу долара. Також скоротилися витрати на освіту у відсотках до ВВП. Загалом спостерігаємо недофінансування освітньої газу: якщо в 2012 р. Обсяг цього показника становив 38905,9 млн грн., то в 2017 р. цей показник зріс до 120536,0 млн грн.

Найбільш суттєвий ріст фактичних видатків на освіту відбувся у 2017 році: +48,3 млрд грн. або 37,3\% до попереднього періоду (рис. 1).

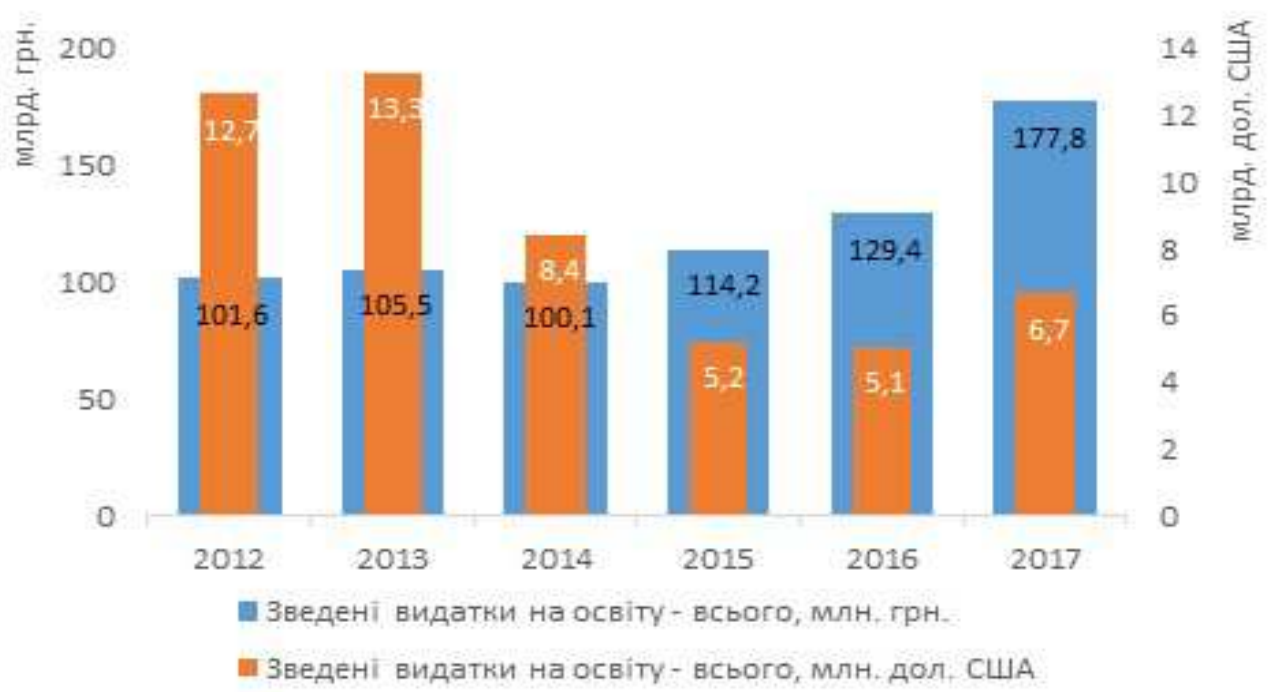

Рис. 1 Зведені витрати на освіту у 2012-2017 роках* *Джерело [3]

Однак, якщо порівнювати обсяг фінансування в еквіваленті дол. США (рис. 1), то обсяг фінансування зменшився на 6,0 млрд дол. США, або на 47,3\% в динаміці, з 12,7 млрд дол. США у 2012 році до 6,7 млрд. дол. США у 2017 році (+ 1,6 млрд дол. США, або 31,9\% в динаміці у 2017 році), що перевищує темпи падіння ВВП (-36,0\%).

Зведені витрати на освіту у відсотках до ВВП України у 2017 році становили 6,0\%. У 2012 - 2013 роки цей показник становив близько $7,2 \%, 2014-6,3 \%, 2015$ рік - 5,7\%, 2016 році - зменшився на 0,3 п.п., 2017 рік - ріст на 0,6 п.п. Тобто, динаміка даного показника не стабільна, та якщо порівнювати цей показник з 2012 роком, витрати на освіту у відсотках до ВВП зменшились на 1,2 п.п. або на 17,6\%. (рис. 2). 
Таблиця 1

Динаміка зведеного бюджету освітньої галузі у 2012-2017 роках*

\begin{tabular}{|c|c|c|c|c|c|c|c|c|c|c|c|c|c|c|c|c|}
\hline & \multicolumn{6}{|c|}{ Роки } & \multicolumn{5}{|c|}{ Відхилення абсолютне } & \multicolumn{5}{|c|}{ Відхилення відносне, \% } \\
\hline & 2012 & 2013 & 2014 & 2015 & 2016 & 2017 & $\begin{array}{c}2013 / \\
2012\end{array}$ & $\begin{array}{c}2014 / \\
2013\end{array}$ & $\begin{array}{c}2015 / \\
2014\end{array}$ & $\begin{array}{c}2016 / \\
2015\end{array}$ & $\begin{array}{c}2017 / \\
2016\end{array}$ & $\begin{array}{c}2013 / \\
2012\end{array}$ & $\begin{array}{c}2014 / \\
2013\end{array}$ & $\begin{array}{c}2015 / \\
2014\end{array}$ & $\begin{array}{c}2016 / \\
2015\end{array}$ & $\begin{array}{c}2017 / \\
2016\end{array}$ \\
\hline $\begin{array}{l}\text { Валовий внутрішній } \\
\text { продукт у фактичних } \\
\text { цінах (ВВП), млн грн. }\end{array}$ & 1404669,0 & 1465198,0 & 1586915,0 & 1988544,0 & 2385367,0 & 2982920,0 & 60529,0 & 121717,0 & 401629,0 & 396823,0 & 597553,0 & 4,3 & 8,3 & 25,3 & 20,0 & 25,1 \\
\hline $\begin{array}{l}\text { Курс долар США до } \\
\text { гривні }\end{array}$ & 8,02 & 7,94 & 11,89 & 21,84 & 25,55 & 26,60 & $-0,08$ & 3,95 & 9,96 & 3,71 & 1,05 & $-1,0$ & 49,8 & 83,8 & 17,0 & 4,1 \\
\hline $\begin{array}{l}\text { Валовий внутрішній } \\
\text { продукт у фактичних } \\
\text { цінах (ВВП), млн дол. } \\
\text { США } \\
\end{array}$ & 175254,5 & 184603,6 & 133503,3 & 91030,9 & 93355,5 & 112154,0 & 9349,1 & $-51100,3$ & $-42472,3$ & 2324,6 & 18798,5 & 5,3 & $-27,7$ & $-31,8$ & 2,6 & 20,1 \\
\hline $\begin{array}{l}\text { Зведені видатки на } \\
\text { освіту - всього, млн } \\
\text { грн. }\end{array}$ & 101561,0 & 105539,0 & 100110,0 & 114194,0 & 129435,0 & 177756,0 & 3978,0 & $-5429,0$ & 14084,0 & 15241,0 & 48321,0 & 3,9 & $-5,1$ & 14,1 & 13,3 & 37,3 \\
\hline $\begin{array}{l}\text { Зведені видатки на } \\
\text { освіту - всього, млн } \\
\text { дол. США } \\
\end{array}$ & 12671,3 & 13297,1 & 8422,0 & 5227,5 & 5065,7 & 6683,4 & 625,8 & $-4875,1$ & $-3194,5$ & $-161,9$ & 1617,7 & 4,9 & $-36,7$ & $-37,9$ & $-3,1$ & 31,9 \\
\hline $\begin{array}{l}\text { Витрати на освіту у } \\
\text { відсотках до ВВП }\end{array}$ & 7,2 & 7,2 & 6,3 & 5,7 & 5,4 & 6,0 & 0,0 & $-0,9$ & $-0,6$ & $-0,3$ & 0,5 & & & & & 9,8 \\
\hline $\begin{array}{l}\text { ВВП освітньої галузі, } \\
\text { млн грн. }\end{array}$ & 71771,0 & 77986,0 & 76068,0 & 82778,0 & 88996,0 & 129074,0 & 6215,0 & $-1918,0$ & 6710,0 & 6218,0 & 40078,0 & 8,7 & $-2,5$ & 8,8 & 7,5 & 45,0 \\
\hline $\begin{array}{l}\text { ВВП освітньої галузі, } \\
\text { млн дол. США }\end{array}$ & 8954,6 & 9825,6 & 6399,4 & 3789,4 & 3483,0 & 4853,0 & 871,1 & $-3426,2$ & $-2610,0$ & $-306,4$ & 1370,0 & 9,7 & $-34,9$ & $-40,8$ & $-8,1$ & 39,3 \\
\hline $\begin{array}{l}\text { Доля у ВВП України, } \\
\%\end{array}$ & 5,1 & 5,3 & 4,8 & 4,2 & 3,7 & 4,3 & 0,2 & $-0,5$ & $-0,6$ & $-0,4$ & 0,6 & & & & & 16,0 \\
\hline $\begin{array}{l}\text { Розмір фінансування } \\
\text { визначеного законо- } \\
\text { давством (10\% від } \\
\text { ВВП), млн грн. } \\
\end{array}$ & 140466,9 & 146519,8 & 158691,5 & 198854,4 & 238536,7 & 298292,0 & 6052,9 & 12171,7 & 40162,9 & 39682,3 & 59755,3 & 4,3 & 8,3 & 25,3 & 20,0 & 25,1 \\
\hline $\begin{array}{l}\text { Недофінансування } \\
\text { освітньої галузі, млн } \\
\text { грн. } \\
\end{array}$ & 38905,9 & 40980,8 & 58581,5 & 84660,4 & 109101,7 & 120536,0 & 2074,9 & 17600,7 & 26078,9 & 24441,3 & 11434,3 & 5,3 & 42,9 & 44,5 & 28,9 & 10,5 \\
\hline $\begin{array}{l}\text { Відсоток недофінан- } \\
\text { сування освітньої га- } \\
\text { лузі, \% }\end{array}$ & 27,7 & 28,0 & 36,9 & 42,6 & 45,7 & 40,4 & 0,3 & 8,9 & 5,7 & 3,2 & $-5,3$ & 1,0 & 32,0 & 15,3 & 7,4 & $-11,7$ \\
\hline
\end{tabular}

*Джерело: [3; 4] 


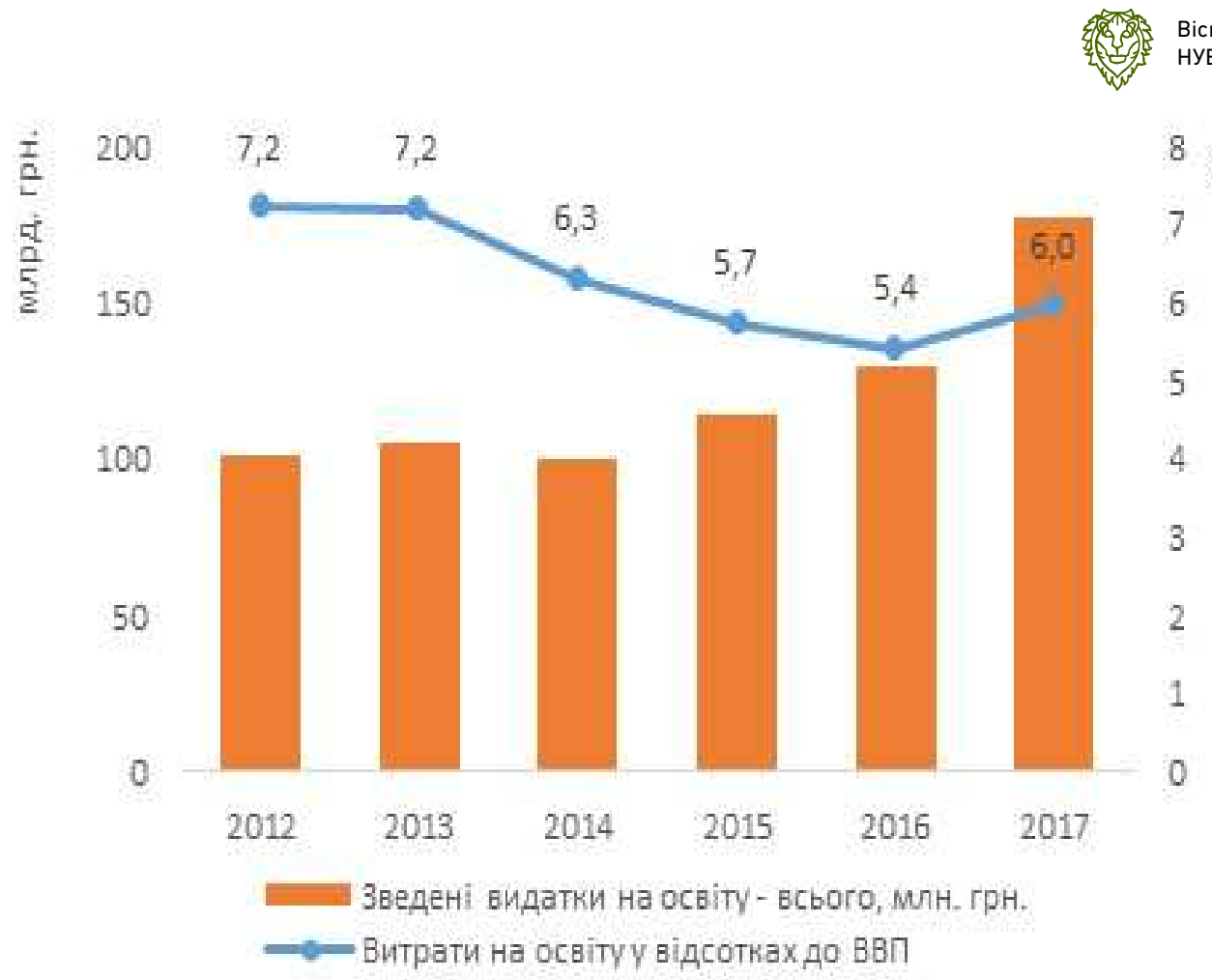

Рис. 2. Витрати на освіту у відсотках до ВВП у 2012-2017 роках* *Джерело [3]

Дані щодо зведених видатків на освіту в розрізі бюджетів фінансування за 2012-2017 роки наведена в табл. 2.

Найбільша питома вага витрат на освіту припадає на місцеві бюджети, а найменше на державний бюджет. Зокрема у 2012 році місцеві бюджети фінансували 32,2\% витрат на освіту, а в 2017 р. такий показник зменшився до $27,9 \%$.

Найбільшу питому вагу фінансового забезпечення було здійснено місцевими бюджетами у 2013 р., а найменшу - у 2016 р. Також можна спостерігати щорічне скорочення фінансування державного бюджету на освіту.

У 2017 році, в порівнянні з 2012 роком, зведені видатки на освіту, збільшились на 75\%, за 2017 рік: $+37 \%$. При цьому загальні зведені видатки зросли на $115 \%$, за 2017 рік: $+26 \%$. Іншими словами, за аналізований період загальні зведені видатки зросли в більшій мірі ніж видатки на освіту, однак у 2017 році темп росту зведених видатків на освіту перевищує темп росту загальних зведених видатків, що забезпечило зростання відсотку видатків на освіту у складі загальних видатків на 1,3 п.п., з $15,5 \%$ у 2016 році до $16,8 \%$ у 2017 році (рис. 3).

Динаміка загальних зведених видатків та зведених видатків на освіту за 2012-2017 роки наведена на рис. 3. 
Таблиця 2

Зведені видатки на освіту у 2012-2017 роках*

\begin{tabular}{|c|c|c|c|c|c|c|}
\hline \multirow{2}{*}{ Роки } & \multicolumn{3}{|c|}{ Зведені видатки на освіту, млн грн. } & \multicolumn{3}{|c|}{$\begin{array}{c}\text { Зведені видатки на освіту у відсотках } \\
\text { до загальних витрат }\end{array}$} \\
\hline & $\begin{array}{l}\text { Місцеві } \\
\text { бюджети }\end{array}$ & $\begin{array}{c}\text { Державний } \\
\text { бюджет }\end{array}$ & $\begin{array}{c}\text { Зведений } \\
\text { бюджет }\end{array}$ & $\begin{array}{l}\text { Місцеві } \\
\text { бюджети }\end{array}$ & $\begin{array}{l}\text { Державний } \\
\text { бюджет }\end{array}$ & $\begin{array}{l}\text { Зведений } \\
\text { бюджет }\end{array}$ \\
\hline \multicolumn{7}{|c|}{ Освіта } \\
\hline 2012 & 71318,0 & 30243,0 & 101561,0 & 32,2 & 11,2 & 20,6 \\
\hline 2013 & 74596,0 & 30943,0 & 105539,0 & 34,2 & 10,8 & 20,9 \\
\hline 2014 & 71432,0 & 28678,0 & 100110,0 & 32,0 & 9,6 & 19,1 \\
\hline 2015 & 84008,0 & 30186,0 & 114194,0 & 30,3 & 7,5 & 16,8 \\
\hline 2016 & 94610,0 & 34825,0 & 129435,0 & 27,3 & 7,1 & 15,5 \\
\hline 2017 & 136616,0 & 41140,0 & 177756,0 & 27,9 & 7,3 & 16,8 \\
\hline \multicolumn{7}{|c|}{ Всього зведені видатки } \\
\hline 2012 & 221233,0 & 271222,0 & 492455,0 & 100 & 100 & 100 \\
\hline 2013 & 218236,0 & 287608,0 & 505844,0 & 100 & 100 & 100 \\
\hline 2014 & 223509,0 & 299617,0 & 523126,0 & 100 & 100 & 100 \\
\hline 2015 & 276940,0 & 402931,0 & 679871,0 & 100 & 100 & 100 \\
\hline 2016 & 346242,0 & 489348,0 & 835590,0 & 100 & 100 & 100 \\
\hline 2017 & 490119,0 & 566641,0 & 1056760,0 & 100 & 100 & 100 \\
\hline
\end{tabular}

*Джерело [3]

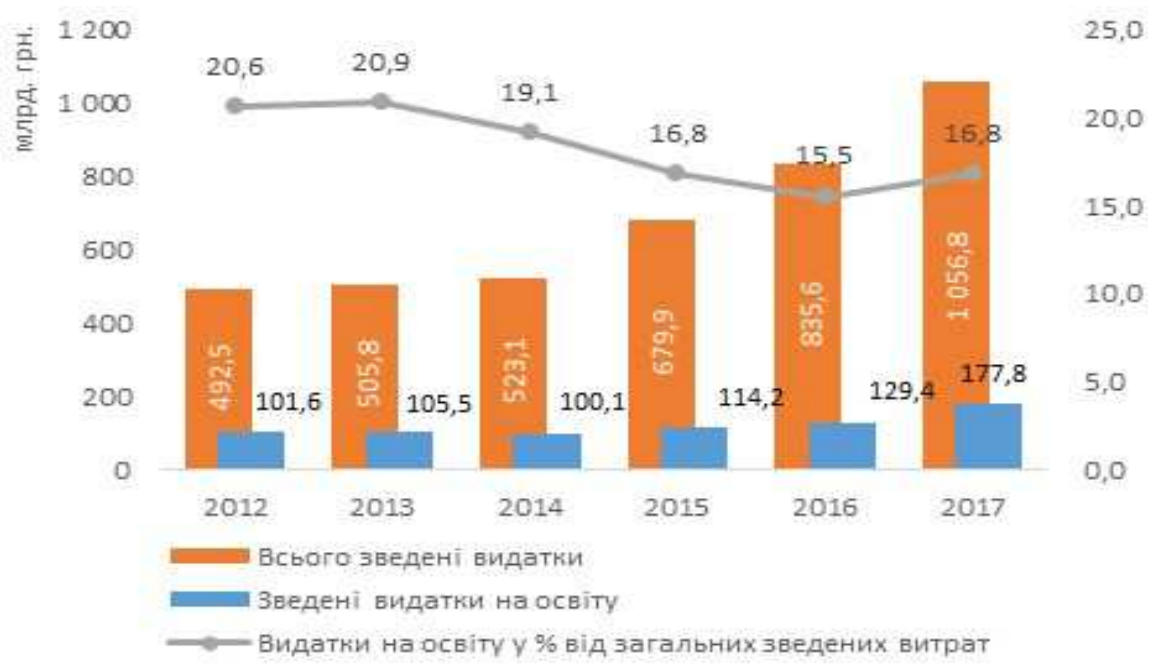

Рис. 3. Загальні зведені видатки та зведені видатки на освіту у 2012-2017 роках*

*Джерело [3]

У 2012 році видатки на освіту становили $20,6 \%$ від загальних зведених витрат, а вже у 2017 році - 16,8\%. Тобто, цей показник за 2012-2017 роки зменшився на 3,8 п.п.

\section{Висновки}

Отже, за результатами проведених досліджень можемо ствер- 
джувати, що за 2012-2017 рр. скорочуються видатки на фінансування освіти, особливо у співвідношенні до курсу долара. Із його зростанням - зменшуються видатки на освіту.

Спостерігається коливання зведених витрати на освіту у відсотках до ВВП України за досліджуваний період. Зокрема такий показник найвищим був у 2012 р., а найнижчий у 2016 р.

Зменшується рівень витрат державних бюджетів на освіту, та автоматично зростають видатки на освіту місцевих бюджетів. За досліджуваний період загальні зведені видатки зросли в більшій мірі ніж видатки на освіту, однак у 2017 році темп росту зведених видатків на освіту перевищує темп росту загальних зведених видатків, що забезпечило зростання відсотку видатків на освіту у складі загальних видатків на 1,3 п.п., з 15,5\% у 2016 році до 16,8\% у 2017 році.

Загалом, для покращення фінансового забезпечення освіти, виходячи із навантаження на місцеві бюджети пропонуємо оптимізувати систему бюджетування в межах місцевих бюджетів та забезпечити раціональність використання коштів державних бюджетів.

Перспективним напрямком подальших досліджень $\epsilon$ обґрунтування методології дослідження та вчасне виявлення зовнішніх та внутрішніх чинників, що впливають на процес фінансового забезпечення освітньої галузі.

1. Вітренко Ю. Освіта як вид економічної діяльності. Економіка України. 2011. № 10. С. 4-15. 2. Головня О. М. Соціально-економічні джерела розбудови освітнього простору України. Економіка $і$ держава. 2011. № 4. C. 31-37. 3. Державна служба статистики України. URL: www.ukrstat.gov.ua (дата звернення: 15.06.2019). 4. URL: http://cost.ua/budget/expenditure/ (дата звернення: 15.06.2019). 5. Заглинська Л. В., Лукомська О. І. Економічна освіта в контексті інвестиційних процесів у галуз оновлення змісту, форм та методів навчання і виховання в закладах освіти. Наукові записки Рівненського державного гуманітарного університету : зб. наук. праць, 2014 Випуск 9 (52). URL: http://irbis-nbuv.gov.ua/cgibin/irbis_nbuv/cgiirbis_64.exe?C21COM=2\&I21DBN=UJRN\&P21DBN=UJRN\&IM AGE_FILE_DOWNLOAD=1\&Image_file_name=PDF/Ozfm_2014_9_25.pdf (дата звернення: 15.06.2019). 6. Інформаційно-аналітичне забезпечення освітньої реформи в Україні : монографія / за ред. С. Л. Лондара ; ДНУ «Інститут освітньої аналітики». К., 2017. 304 с. 7. Колот А. М. Вища освіта як чинник формування людського капіталу: сучасний стан, тенденції розвитку. Вісник Прикарпатського університету. Економіка. 2007. Вип. 4. С. 12-16. 8. Красовська О. Ю. Сучасні моделі реалізації бізнес-освіти в умовах глобалізації світового освітнього простору Бюлетень Міжнародного Нобелівського форуму. 2012. № 1(5). Т. 2. С. 167-171. 9. Освітня галузь України: аналіз тенденцій, нововведень і перспектив ГО «Публічний аудит» 29.07.2017. URL: http://publicaudit.com.ua/reports-on-audit/osvitnya-galuz-v-ukrayini-analiztendentsij-novovveden-i-perspektiv/ (дата звернення: 15.06.2019). 
Серія «Економічні науки»

Випуск 4(84) 2018 р.

\section{REFERENCES:}

1. Vitrenko Yu. Osvita yak vyd ekonomichnoi diialnosti. Ekonomika Ukrainy. 2011. № 10. S. 4-15. 2. Holovnia 0. M. Sotsialno-ekonomichni dzherela rozbudovy osvitnoho prostoru Ukrainy. Ekonomika i derzhava. 2011. № 4. S. 31-37. 3. Derzhavna sluzhba statystyky Ukrainy. URL: www.ukrstat.gov.ua (data zvernennia: 15.06.2019). 4. URL: http://cost.ua/budget/expenditure/ (data zvernennia: 15.06.2019). 5. Zahlynska L. V., Lukomska O. I. Ekonomichna osvita $\mathrm{v}$ konteksti investytsiinykh protsesiv $u$ haluz onovlennia zmistu, form ta metodiv navchannia i vykhovannia $v$ zakladakh osvity. Naukovi zapysky Rivnenskoho derzhavnoho humanitarnoho universytetu : zb. nauk. prats, 2014 Vypusk 9 (52). URL: http://irbis-nbuv.gov.ua/cgibin/irbis_nbuv/cgiirbis_64.exe?C21COM=2\&I21DBN=UJRN\&P21DBN=UJRN\&IM AGE_FILE_DOWNLOAD=1\&Image_file_name=PDF/Ozfm_2014_9_25.pdf (data zvernennia: 15.06.2019). 6. Informatsiino-analitychne zabezpechennia osvitnoi reformy v Ukraini : monohrafiia / za red. S. L. Londara ; DNU «Instytut osvitnoi analityky». K., 2017. 304 s. 7. Kolot A. M. Vyshcha osvita yak chynnyk formuvannia liudskoho kapitalu: suchasnyi stan, tendentsii rozvytku. Visnyk Prykarpatskoho universytetu. Ekonomika. 2007. Vyp. 4. S. 12-16. 8. Krasovska 0 . Yu. Suchasni modeli realizatsii biznes-osvity $v$ umovakh hlobalizatsii svitovoho osvitnoho prostoru. Biuleten Mizhnarodnoho Nobelivskoho forumu. 2012. № 1(5). T. 2. S. 167-171. 9. Osvitnia haluz Ukrainy: analiz tendentsii, novovveden i perspektyv HO «Publichnyi audyt» 29.07.2017. URL: http://publicaudit.com.ua/reports-on-audit/osvitnya-galuz-v-ukrayini-analiztendentsij-novovveden-i-perspektiv/ (data zvernennia: 15.06.2019).

Рецензент: д.е.н., професор Левицька С. О. (НУВГП)

Savina N. B., Doctor of Economics, Professor (National University of Water and Environmental Engineering, Rivne), Doroshchuk N. I., Post-graduate Student (National University of Water and Environmental Engineering, Rivne)

\section{FINANCIAL PROVISIONS OF THE EDUCATIONAL INDUSTRY NATIONAL ECONOMY}

The article deals with analysis of total budget dynamics of educational area during 2012-2017. It was defined that actual expenditure on

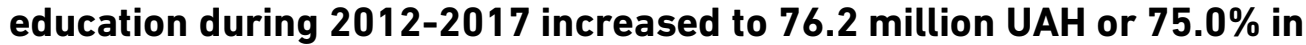
dynamics, from 101.6 billion UAH in 2012 to 177.8 billion in 2017. Total expenditure on education during 2012-2017 suggests that the sufficient expenditure increase took place in 2017 , extra 48.3 billion UAH or $37.3 \%$ to previous period. The author analyzed expenditure on education in percentages to GDP during 2012-2017 and defined that the highest indicator was in 2012 and the lowest - in 2016. As a result of the research it was proved that the largest share of education expenditure falls on local budgets, but the lowest on state budget. In 
2012, local budgets financed $32.2 \%$ of education expenditures, and in 2017 this indicator decreased to $27.9 \%$. In order to improve the financial support of education, the author has suggested optimization of budgeting system within the local budgets and to ensure the rational use of state budget funds.

Keywords: education, expenditure, total expenditure, budget of educational area, total educational expenditure, financing of educational area.

Савина Н. Б., д.э.н., проф. (Национальный университет водного хозяйства и природопользования, г. Ровно), Дорощук Н. И., аспирант (Национальный университет водного хозяйства и природопользования, г. Ровно)

\section{ТЕНДЕНЦИИ ФИНАНСОВОГО ОБЕСПЕЧЕНИЯ ОБРАЗОВАНИЯ НАЦИОНАЛЬНОЙ ЭКОНОМИКИ}

В статье осуществлен анализ динамики сводного бюджета образования в 2012-2017 годах и установлено, что фактические расходы на образование по 2012-2017 годы выросли на 76,2 млн грн. или на 75,0\% в динамике, с 101,6 млрд грн. в 2012 году до

177,8 млрд грн. в 2017 году. Обоснованно сведены расходы на образование в 2012-2017 годах, доказано, что наиболее существенный рост фактических расходов на образование состоялся в 2017 году: +48,3 млрд грн. или 37,3\% к предыдущему периоду. Автором проанализированы расходы на образование в процентах к ВВП в 2012-2017 годах и установлено, что такой показатель высоким был в 2012 г., а самый низкий в 2016 г. По результатам исследования автором доказано, что наибольший удельный вес расходов на образование приходится на местные бюджеты, а меньше на государственный бюджет. В частности, в 2012 году местные бюджеты финансировали $32,2 \%$ расходов на образование, а в 2017 , такой показатель уменьшился до 27,9\%. Для улучшения финансового обеспечения образования, исходя из нагрузки на местные бюджеты автором предложено оптимизировать систему бюджетирования в пределах местных бюджетов и обеспечить рациональность использования средств государственных бюджетов. Ключевые слова: образование, расходы, возведенные расходы, бюджет образования, построенные расходы на образование, финансирование образования. 